\title{
Glucagon-Like Peptide 2 Enhances Maltase-Glucoamylase and Sucrase-Isomaltase Gene Expression and Activity in Parenterally Fed Premature Neonatal Piglets
}

\author{
YVETTE M. PETERSEN, JAN ELNIF, METTE SCHMIDT, AND PER T. SANGILD \\ Division of Animal Nutrition [Y.M.P, J.E., P.T.S], Division of Reproduction [M.S.], Royal Veterinary and \\ Agricultural University, Copenhagen, DK-1870, Frederiksberg, Denmark
}

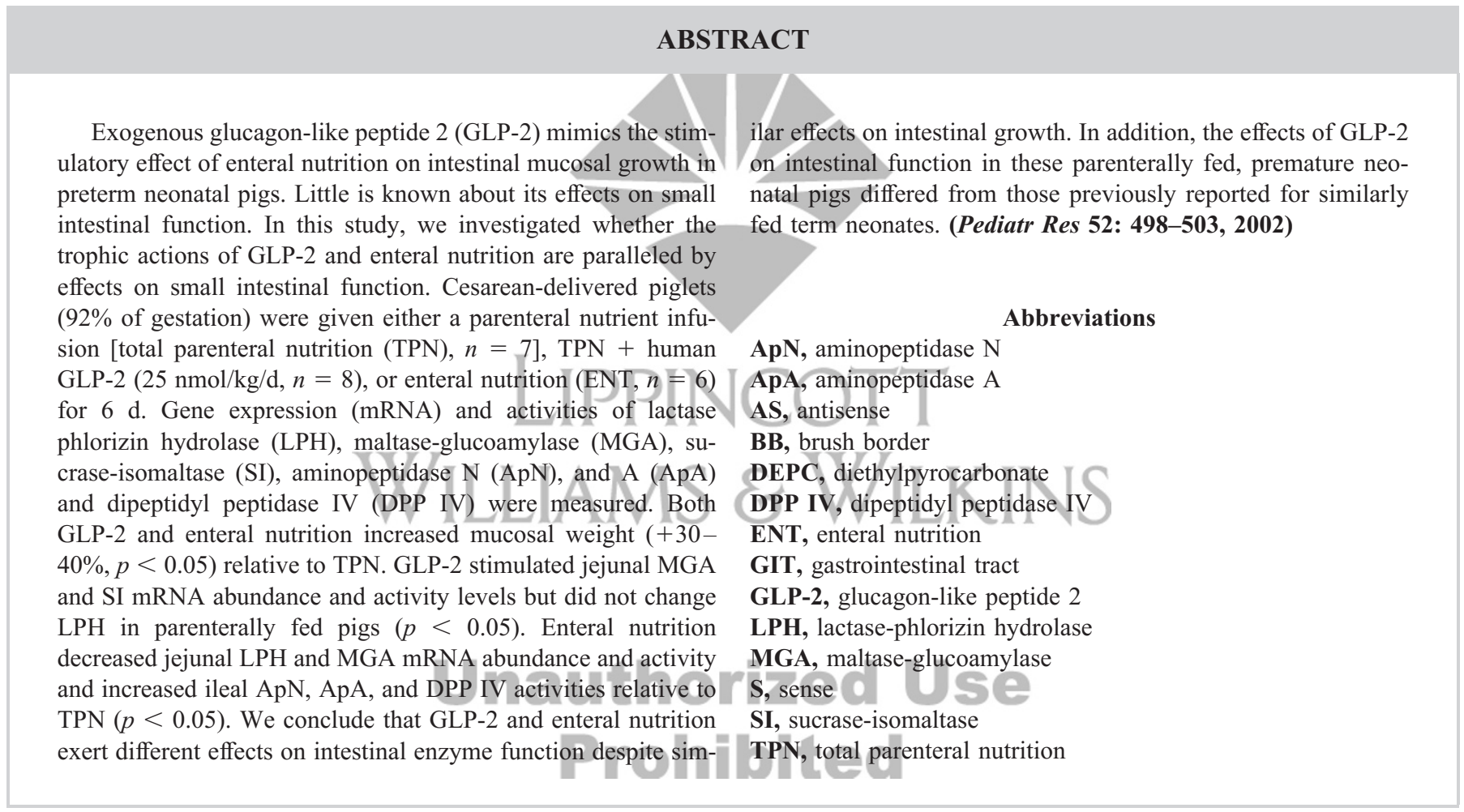

TPN is frequently administered to premature infants unable to tolerate enteral nutrition. TPN provides systemic energy and nutrients but has been associated with intestinal atrophy, abnormal BB hydrolase activities, and reduced circulating GLP-2 concentrations (1-5). GLP-2 is a 33-amino acid peptide released from the specific post-translational cleaving of the proglucagon gene in the enteroendocrine L cells of the small intestine. This gut peptide stimulates significant mucosal proliferation (6), hexose transport

Received July 24, 2001; accepted April 19, 2002.

Correspondence: Per T. Sangild, Division of Animal Nutrition, Royal Veterinary and Agricultural University, 3 Grønnegårdsvej, DK-1870 Frederiksberg, Copenhagen, Denmark; e-mail: psa@kvl.dk

Supported by a grant from the Danish Agricultural and Veterinary Research Council (Program 9702803).

DOI: 10.1203/01.PDR.0000030884.86822.E4
(7), and duodenal hydrolase activity (8), seemingly via a specific G-protein-coupled receptor present in the small intestine (9). GLP-2 is released in response to enteral nutrient intake $(5,10)$ and is thought to mediate the response of the small intestine to enteral nutrients (11). Recently, however, it has been shown that GLP-2 stimulates intestinal growth by inhibiting apoptosis and proteolysis, and enteral nutrition also inhibits apoptosis but furthermore increases protein synthesis and cell proliferation (11). Thus, despite the similarity in the extent of small intestinal mucosal growth induced by GLP-2 and enteral nutrition, the mechanisms involved are not identical. This, however, does not preclude the possibility that GLP-2 partially mediates the effect of enteral nutrition in the small intestine.

There is some conflicting evidence in the literature as to the effect of TPN on BB enzyme activity in the small intestine. 
Some investigators $(2,12,13)$ report significant decreases in major enzyme activities (lactase, maltase, sucrase, aminopeptidase, and dipeptidyl peptidase), whereas others report marked increases $(3,4)$ during TPN. Regardless of the differences in these results, it is well recognized that the activity of $\mathrm{BB}$ hydrolases cannot be sustained at normal levels by parenteral nutrition alone. GLP-2 has been reported to enhance small intestinal function by specifically increasing SI mRNA levels (14) and sodium-glucose transporter 1 transport activity (7) in adult rats and MGA gene expression and activity in parenterally fed, term-delivered neonates (15). Currently, the effect of GLP-2 on small intestinal function in premature neonates remains to be determined, despite the known trophic effects.

We hypothesized that 1) exogenous GLP-2 would selectively stimulate BB hydrolase gene expression and activities in prematurely delivered neonatal pigs maintained on TPN, and 2) that $B B$ hydrolase gene expression and activities would differ in enterally and parenterally fed piglets. Given that BB hydrolases are subject to differential regulation by hormones and nutrients during development, we wanted to investigate the gene expression and activity of the six major BB hydrolases (LPH, MGA, SI, ApN, ApA, and DPP IV) after $6 \mathrm{~d}$ of either TPN, TPN and GLP-2, or enteral nutrition in premature neonatal piglets. An additional aim of the study was to compare the $\mathrm{BB}$ hydrolase function of these premature neonates with that recently published for term neonates (15), so as to establish whether the effects of GLP-2 on small intestinal function are dependent on gestational age at birth.

\section{MATERIALS AND METHODS}

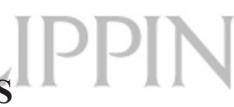

Animals and surgical protocols. A total of 22 crossbred pigs (Large White $\times$ Landrace) were delivered preterm $(105 \pm 2 \mathrm{~d}$, term $=114 \pm 2 \mathrm{~d}$ ) by cesarean section from three different litters. Twenty hours before delivery, pregnant sows were injected with prostaglandin $\mathrm{F}_{2}\left[\mathrm{PGF}_{2} ; 175 \mu \mathrm{g}\right.$ i.m., cloprostenol (Estrumate), Pitman-Moore, Harefield, U.K.] to initiate the normal metabolic and endocrine changes occurring in fetuses and sows before spontaneous delivery (16). Sedation and anesthesia of the sows has been described previously (11). Premature piglets were kept individually in infant incubators (Air-Shields Inc., Hatboro, PA, U.S.A.) maintained at $32-34^{\circ} \mathrm{C}, 80-100 \%$ moisture and extra oxygen supply (1-2 L/min). Pigs from each litter were assigned to receive TPN $(n=7)$, TPN plus GLP-2 $(n=8)$, or enteral nutrition (ENT, $n=6$ ) with sow milk for $6 \mathrm{~d}$ after delivery. While still anesthetized, the premature piglets assigned to the TPN and GLP-2 groups were fitted with two vascular catheters, one inserted in the dorsal aorta via the umbilical artery (4F infant feeding tube, Portex, Kent, U.K.) and another in the umbilical vein (5F infant feeding tube, PharmaPlast, Lynge, Denmark) via the transected cord vessels. Likewise, pigs in the ENT group were also fitted with a dorsal aorta catheter, and an orogastric tube $(6 \mathrm{~F}$ infant feeding tube, PharmaPlast) to be used for enteral feeding. Catheters were sutured to the cord, then to the skin, and, finally, a cotton body suit was fitted onto each pig to protect the catheters.

At the end of the experiment, the piglets were killed and the entire small intestine distal to the ligament of Treitz was immediately flushed with ice-cold saline. The small intestine was divided into two equal segments, a tissue sample (about 10 $\mathrm{cm}$ ) was obtained from the proximal half of first segment and designated the jejunum, and another tissue sample was obtained from the distal half of the second segment and designated the ileum. The samples were snap-frozen in liquid nitrogen and stored at $-70^{\circ} \mathrm{C}$ until further analysis. In addition, a $10-\mathrm{cm}$ piece was removed, opened along its length, and the mucosa removed by gentle scraping with a plastic slide. The proportion of dry mucosa was determined after drying both the mucosa and the muscularis layers at $50^{\circ} \mathrm{C}$ for $72 \mathrm{~h}$. Adrenals, heart, liver, lung, kidney, pancreas, spleen, and stomach were weighed. All procedures were approved by the National Committee on Animal Experimentation, Denmark.

TPN solution composition and administration. The TPN and GLP-2 piglets received an elemental nutrient solution continuously via the umbilical venous catheter. The nutrient solution contained free amino acids (45.5 g amino acids/L; Vamin, 18F), glucose $(72.5 \mathrm{~g} / \mathrm{L})$, and lipid $(30.7 \mathrm{~g} / \mathrm{L}$; Intralipid), all supplied by KABI Pharmacia, Copenhagen, Denmark. Mineral and vitamin solutions were added [Calcium-Sandoz, $2 \%$, Addiphos, $0.6 \%$, Peditrace, $0.6 \%$, Vitalipid, $1.0 \%$, and Soluvit, $0.1 \%$; KABI Pharmacia). The nutrient concentrations were chosen based on those used and validated previously in studies on newborn TPN-fed pigs (17). The TPN solution was administered continuously from $6 \mathrm{~h}$ after birth and, after an initial 2-d period in which the animals received $50 \%$ of the total intake, the animals received $550 \mathrm{~kJ} / \mathrm{kg} / \mathrm{d}$, $8 \mathrm{~g}$ amino $\mathrm{acid} / \mathrm{kg} / \mathrm{d}$, and a fluid intake of $170 \mathrm{~mL} / \mathrm{kg} / \mathrm{d}$ for the remainder of the experimental period. To provide some passive immunity, the TPN-fed piglets were given a total of $15 \mathrm{~mL}$ maternal serum over the first $24 \mathrm{~h}$ via the arterial catheter. The serum was produced from maternal blood collected from a uterine vein at the time of surgery. Together with the TPN solution that was infused into the umbilical vein, the pigs received two daily 2-h infusions of human GLP-2 (12.5 nmol/kg/2 h, a generous gift from L. Thim, Novo Nordisk, Bagsværd, Denmark), or the control ( $0.1 \%$ porcine serum albumin in $0.9 \%$ buffered saline) starting at $0800 \mathrm{~h}$ and $1600 \mathrm{~h}$. The ENT group received a continuous orogastric infusion of sow's colostrum (for $1 \mathrm{~d}$ ) or milk (for $5 \mathrm{~d}$ ) at an hourly rate identical to that of the TPN solution, providing approximately $700 \mathrm{~kJ} / \mathrm{kg} / \mathrm{d}, 12 \mathrm{~g}$ protein $\mathrm{kg} / \mathrm{d}$. Each day during the 6-d period, the pigs were weighed to adjust their nutrient infusion rates. On the last day of the experiment (d 6), a 2-mL arterial blood sample was collected at $0800 \mathrm{~h}$ before the GLP-2 and vehicle infusions.

GLP-2 RIA. Circulating GLP-2 levels were measured with an $\mathrm{N}$-terminal-specific antiserum. This assay solely detects the $\mathrm{N}$-terminal region of porcine GLP-2 and has been thoroughly described previously (18). The experimental limit of detection of this assay is $5 \mathrm{pM}$ and the intra-assay coefficient of variation is $5 \%$ at a concentration of $40 \mathrm{pM}$.

RNA extraction and reverse transcription PCR. Total RNA was extracted from individually frozen samples $(50-100 \mathrm{mg})$ of jejunum and ileum (19). RNA was dissolved in $0.1 \%$ DEPC-treated water and recovery $\left(\mathrm{A}_{260} \mathrm{~nm}\right)$ and purity $\left(\mathrm{A}_{260}\right.$ $\left.\mathrm{nm} / \mathrm{A}_{280} \mathrm{~nm}\right)$ determined with a UV spectrophotometer (GeneQuant pro, Amersham Pharmacia Biotech, Cambridge, U.K.). RNA ( $1 \mu \mathrm{g})$ quality was assessed on a formaldehyde gel based on the integrity of the $28 \mathrm{~S}$ and $18 \mathrm{~S}$. Individual samples 
of total RNA $(3 \mu \mathrm{g})$, random decamer primers $(50 \mu \mathrm{M}$; Ambion, Austin, TX, U.S.A.), dNTP mix (10 mM each dGTP, dATP, dTTP, dCTP; Invitrogen, Groningen, The Netherlands), and DEPC-treated water were made up to a total volume of 12 $\mu \mathrm{L}$ in thin-walled PCR microtubes (ABgene, Epsom, Surrey, U.K.). This RNA mix was denatured at $65^{\circ} \mathrm{C}(5 \mathrm{~min})$ then $25^{\circ} \mathrm{C}$ $(10 \mathrm{~min})$ and stored on ice. In a separate tube, a reverse transcription reaction master mix consisting of $5 \mathrm{X}$ first-strand buffer [250 mM Tris- $\mathrm{HCl}(\mathrm{pH} 8.3), 375 \mathrm{mM} \mathrm{KCl}, 15 \mathrm{mM}$ $\mathrm{MgCl}_{2}$; Invitrogen], DTT (100 mM; Invitrogen), RNasin ribonuclease inhibitor (20 U; Promega, Madison, WI, U.S.A.), and M-MLV reverse transcriptase (200 U; Invitrogen) was prepared and $8 \mu \mathrm{L}$ added to each RNA mix. The RNA was reverse transcribed into cDNA by incubating at $42^{\circ} \mathrm{C}(50 \mathrm{~min})$, then $94^{\circ} \mathrm{C}(10 \mathrm{~min})$, and then cooled on ice.

PCR amplification of BB enzyme cDNA was performed on individual samples. Three microliters of the cDNA from the reverse transcription reaction were added to $17 \mu \mathrm{L}$ of a PCR master mix consisting of 10X PCR buffer minus $\mathrm{Mg}(200 \mathrm{mM}$ Tris-HCl, pH 8.4, $500 \mathrm{mM} \mathrm{KCl}$; Invitrogen), dNTP mix (10 $\mathrm{mM}), \mathrm{MgCl}_{2}$ (50 mM; Invitrogen), autoclaved distilled water and Taq DNA polymerase (1 U; Invitrogen), 18S rRNA internal standards (1 $\mu \mathrm{L}$; Ambion) and a specific $\mathrm{S}$ and AS oligonucleotide pair (Table 1) (0.5 $\mu \mathrm{M}$ each; TAG, Copenhagen, Denmark). The samples were denatured in a thermal cycler (PTC-100, MJ Research, Cambridge, MA, U.S.A.) at $95^{\circ} \mathrm{C}$ for 2 min and underwent amplification cycles with denaturation at $95^{\circ} \mathrm{C}$ for $1 \mathrm{~min}$, annealing for $30 \mathrm{~s}$ at temperatures between $51^{\circ} \mathrm{C}$ and $58^{\circ} \mathrm{C}$, and extension for $1 \mathrm{~min}$ at $72^{\circ} \mathrm{C}$. At the end of the cycles, an additional extension at $72^{\circ} \mathrm{C}$ for $10 \mathrm{~min}$ was performed and the samples were then cooled to $4^{\circ} \mathrm{C}$. To control for the absence of genomic DNA contamination, $\mathrm{PCR}$ reactions were carried out on samples in which the reverse transcriptase enzyme had been excluded in the reverse transcription reaction. Amplification products were electrophoresed on an agarose gel (1\%; BDH Lab, Poole, U.K.) in Tris borate EDTA buffer and visualized by ethidium bromide staining $(0.15 \%)$.

In the neonate pig gut, disaccharidase activities tend to be highest in the jejunum and peptidase activities highest in the ileum (20). Based on this observation, the relative abundance of disac-

Table 1. Oligonucleotides sense and antisense sequences, annealing temperatures, and cycle numbers

\begin{tabular}{|c|c|}
\hline $\begin{array}{l}\text { Oligonucleotides name, annealing } \\
\text { temperature, and cycle number }\end{array}$ & Sense and antisense sequences \\
\hline LPH S & 5'-CTCAGGTGTACAAGTTCT-3' \\
\hline LPH AS $\left(51^{\circ} \mathrm{C}, 26\right.$ cycles $)$ & 5'-AGCATGAAGTGCAAGAAG-3' \\
\hline MGA S & 5'-CAGAAGCTGCCAAGACTGTG-3' \\
\hline MGA AS $\left(56^{\circ} \mathrm{C}, 31\right.$ cycles $)$ & 5'-AGAACTGTTGGTGCACATCC-3' \\
\hline SI S & 5'-TGGCCATCCAGTCATGCC-3' \\
\hline SI AS $\left(58^{\circ} \mathrm{C}, 30\right.$ cycles $)$ & 5'-CCACCACTCTGCTGTGGA-3' \\
\hline ApN S & 5'-ACATCACTCTCATCCACCCТ-3' \\
\hline $\operatorname{ApN}$ AS $\left(58^{\circ} \mathrm{C}, 20\right.$ cycles $)$ & 5'-GCAATCACAGTGACAACTCG-3' \\
\hline ApA S & 5'-GTCTCTACCACCTGACGAT-3' \\
\hline $\operatorname{ApA} \operatorname{AS}\left(56^{\circ} \mathrm{C}, 22\right.$ cycles $)$ & 5'-CTCTGTAAGTGATGAGTCC-3' \\
\hline DPP IV S & 5'-CCTCCGGCGTCTGTGTTA-3' \\
\hline DPP IV AS $\left(56^{\circ} \mathrm{C}, 23\right.$ cycles $)$ & 5'-TGGATTCAGCTCACAGCT-3' \\
\hline 18S rRNA S & 5'-GATACCGCAGCTAGGAAT-3' \\
\hline $18 \mathrm{~S}$ rRNA AS $\left(56^{\circ} \mathrm{C}, 18\right.$ cycles $)$ & 5'-ATCTGTCAATCCTGTCCG-3' \\
\hline
\end{tabular}

charidase mRNA was determined solely in the jejunum and peptidase mRNA in the ileum. To compare enzyme mRNA levels among the TPN, GLP-2, and ENT piglets we first determined the optimal annealing temperature for each primer set (Table 1). Using a pooled sample of cDNA, the range of PCR cycles over which the amplification efficiency of the reaction was at its maximum and remained constant, for both the specific primer set and the $18 \mathrm{~S}$ rRNA standards, was determined. A number of cycles within the linear range of amplification of each primer set were selected and the PCR reactions performed on individual samples for comparison. The relative abundance of the enzyme PCR products on the gels were quantified by OD measurements of PCR bands (Image Pro Plus 4.1 software, Media Cybernetics, Silver Spring, MD, U.S.A.) on digitalized pictures of ethidium-stained gels (BioCapt 97 software, Vilber Lourmat, Cedex, France). The density of each band representing the abundance of enzyme mRNA was expressed relative to the density of the corresponding 18s rRNA band. Finally, the ratios between these enzyme mRNA values in GLP-2 and ENT piglets were calculated relative to that of TPN-administered piglets. To confirm the identity of each PCR product, the cDNA was extracted from the gel (QIAquick gel extraction kit, QIAGEN, Crawley, West Sussex, U.K.), sequenced (TAG Copenhagen, Copenhagen, Denmark), and entered into BLAST (Basic Local Alignment Search Tool), a set of similarity search programs designed to explore all of the available sequence databases that can be accessed through the Web site of the National Center for Biotechnology Information, available at http://www.ncbi.nlm.nih.gov/.

Primers. Oligonucleotides were designed to identify MGA (491 bp, NM_004668), ApN (459 bp; Z29522), ApA (554 bp; U66371), and DPP IV (587 bp; X73277). Oligonucleotides to recognize pig LPH were designed from regions of high homology among LPH cDNA sequences from man (NM_002299), rat (X56747), and rabbit (Z27167). Oligonucleotides to recognize pig SI were designed from regions of high homology between SI cDNA sequences from man (NM_001041) and rat (NM 013061). The oligonucleotides recognized a 540- and a 484-bp product forLPH and SI, respectively.

Enzyme activity assays. Disaccharidase and peptidase activities were determined in both the jejunum and ileum. Enzyme activities were determined as previously described (20). Briefly, frozen intestinal tissue was homogenized in 1\% Triton $\mathrm{X}-100$ (6 mL per gram tissue) and the homogenates assayed for disaccharidase and peptidase activities. Sucrose $(0.01 \mathrm{M}$; no. 194018, ICN, Aurora, OH, U.S.A.) and lactose (0.12 M; L-3625, Sigma Chemical) dissolved in sodium maleate buffer (50 mM, pH 6.0) were used as substrates for LPH (EC 3.2.1.23-62) and SI (EC 3.2.1.48-10), respectively. Maltose (0.0112 M; L-5885, Sigma Chemical) was used to measure maltase activity that represents the combined activity of MGA (EC 3.2.1.20) and SI. ApN (EC 3.4.11.2), DPP IV (EC 3.4.14.5), and ApA (EC 3.4.11.7) activities were measured using three peptidase-specific substrate solutions: $10 \mathrm{mM}$ L-alanine-4-nitroanilide (Merck, Darmstadt, Germany) in 50 $\mathrm{mM}$ Tris-HCl, $\mathrm{pH}$ 7.3, $15 \mathrm{mM}$ glycyl-ı-proline-4-nitro-anilide (Bachem, Bubendorf, Switzerland) in $50 \mathrm{mM}$ Tris-HCl, $\mathrm{pH}$ 8.0 , and $10 \mathrm{mM} \alpha$-L-glutamic acid 4-nitroanilide (synthesized at the Institute of Protein Chemistry, Hørsholm, Denmark) in 
$50 \mathrm{mM}$ Tris- $\mathrm{HCl}, \mathrm{pH} 8.0$, respectively. One unit (U) of activity represents $1 \mu \mathrm{mol}$ of substrate hydrolyzed per min at $37^{\circ} \mathrm{C}$.

Statistical analysis. Data are expressed as mean \pm SEM. The data were analyzed by ANOVA using a general linear model and with treatment (TPN, GLP-2, and ENT), intestinal region (jejunum, ileum), and litter as fixed effects within SAS (version 6.03, SAS Institute, Cary, NC, U.S.A.). A $t$ test was used to compare mRNA abundance in GLP-2 or ENT pigs relative to TPN. Significance was assigned at $p \leq 0.05$ for all statistical evaluations.

\section{RESULTS}

Plasma GLP-2 concentrations. Basal plasma GLP-2 (pM, mean \pm SEM) concentrations were $28 \pm 7$ in TPN piglets, 67 \pm 16 in GLP-2, and $56 \pm 9$ in ENT piglets at the end of the experiment (11).

Organ weights. Piglet body weights at birth and after $6 \mathrm{~d}$ were similar among the three groups (Table 2). Small intestinal weight and percentage of dry mucosa were increased $(p<$ 0.01 ) in both GLP-2 and ENT piglets relative to TPN controls (Table 2). Pancreas weight in ENT pigs was elevated relative to TPN controls. None of the other organs weighed (adrenals, heart, liver, lung, kidney, spleen, and stomach) were different among the three groups of piglets (Table 2).

Enzyme gene expression and activity. In the jejunum, GLP-2 significantly increased MGA and SI mRNA abundance and activity relative to TPN, with no effect on LPH (Fig. 1). Enteral nutrition decreased MGA and LPH mRNA abundance and activities, with no effect on SI, relative to TPN controls (Fig. 1). In the ileum, MGA, LPH, and SI activities were not different among TPN, GLP-2, and ENT piglets (data not shown). Across the entire intestine, MGA and SI mean activities were significantly increased (55-60\%) in GLP-2 piglets and LPH mean activity significantly decreased (about 60\%) in ENT piglets, relative to TPN controls (data not shown). In parenterally fed piglets (TPN, GLP-2), MGA, LPH, and SI activities were 2- to 3 -fold higher in the jejunum relative to the ileum, but in enterally fed piglets no regional differences were present.

In the jejunum, GLP-2 increased ApN $(p=0.05)$ and enteral nutrition increased ApA $(p<0.0001)$ activity, relative to TPN controls (data not shown). In the ileum, GLP-2 significantly increased ileal DPP IV mRNA levels, compared with TPN controls, but had no effect on the mRNA abundance or activities of ileal ApN and ApA (Fig. 2). Enteral nutrition increased the activities of ApN, ApA, and DPP IV in the ileum, relative to TPN, without having any effect on the corresponding enzyme mRNA (Fig. 2). Across the entire intestine, small intestine mean ApN activity was increased in GLP-2 piglets $(p<$ $0.02)$ and ApA and DPP IV mean activities significantly increased in ENT piglets $(p<0.003)$, relative to TPN controls (data not shown). In parenterally fed piglets (TPN, GLP-2), ApN activity was significantly increased $(p<0.01)$ in the jejunum relative to the ileum (data not shown). Within each group, regional differences were not observed in ApA and DPP IV activities. In enterally fed piglets, ApN and DPP IV activities were higher in the ileum and no regional difference was observed in ApA activity.

\section{DISCUSSION}

The goals of this study were 1) to determine the effect of exogenous GLP-2 on BB enzyme gene expression and activities in parenterally fed pigs, and 2) to compare the effect of parenteral versus enteral nutrition on BB enzyme gene expression and activities in premature neonatal pigs. It is well accepted that TPN leads to significant reductions in small intestinal mucosal growth and morphology $(1,5)$. The effects of TPN on small intestinal function are, however, not as straightforward $(2,3)$, but nevertheless indicate that the presence of luminal contents is essential for the maintenance of normal small intestinal enzyme activity, within the GIT. In recent years, the administration of growth factor-supplemented TPN or partial enteral nutrition has been investigated as a means of infibiting the intestinal atrophy and BB enzyme dysfunction associated with TPN. We have recently demonstrated that GLP-2 maintains small intestinal morphology in parenterally fed, prematurely delivered neonatal pigs to a level similar to enteral nutrition (10), and Park et al. (21) report that partial enteral nutrition increases intestinal mass and disaccharidase activity in neonatal pigs, relative to TPN controls.

In this study, we have shown that GLP-2 stimulates specific BB hydrolase (maltase and SI) activities in parenterally fed, prematurely delivered neonatal piglets. The stimulatory effect

Table 2. Body and organ weights in piglets administered TPN, GLP-2, or ENT for $6 d$

\begin{tabular}{lccc}
\hline & TPN & GLP-2 & ENT \\
\hline No. & 7 & 8 & 6 \\
Birth body weight $(\mathrm{kg})$ & $1.36 \pm 0.03$ & $1.34 \pm 0.04$ & $1.30 \pm 0.03$ \\
Sacrifice body weight $(\mathrm{kg})$ & $1.54 \pm 0.04$ & $1.46 \pm 0.05$ & $1.46 \pm 0.02$ \\
Small intestinal weight $(\mathrm{g})$ & $30.0 \pm 1.0$ & $37.5 \pm 1.6^{*}$ & $43.8 \pm 1.3^{*}$ \\
Intestinal dry mucosa (\%) & $53.5 \pm 1.3$ & $65.7 \pm 1.1^{*}$ & $62.5 \pm 1.2^{*}$ \\
Adrenals (mg) & $207 \pm 11$ & $204 \pm 10$ & $232 \pm 16$ \\
Heart (g) & $11.8 \pm 0.8$ & $11.2 \pm 0.8$ & $10.9 \pm 0.4$ \\
Liver (g) & $50.8 \pm 2.3$ & $44.6 \pm 4.4$ & $44.1 \pm 3.4$ \\
Lung (g) & $26.5 \pm 1.9$ & $25.2 \pm 2.0$ & $23.9 \pm 1.1$ \\
Kidney (g) & $13.6 \pm 1.2$ & $13.6 \pm 1.2$ & $14.7 \pm 0.9$ \\
Pancreas (g) & $1.98 \pm 0.11$ & $1.99 \pm 0.17$ & $2.67 \pm 0.07^{*}$ \\
Spleen (g) & $2.79 \pm 0.20$ & $2.52 \pm 0.36$ & $2.40 \pm 0.16$ \\
Stomach $(\mathrm{g})$ & $7.37 \pm 0.35$ & $7.27 \pm 0.51$ & $7.32 \pm 0.30$ \\
\hline
\end{tabular}

Values are expressed as means \pm SEM of the number of animals indicated in each column.

$* p<0.05$ relative to TPN. 
of GLP-2 on maltase has previously been reported in termdelivered neonatal pigs (15) and adult rats (14), respectively. We suggest that the suppression of proteolysis and villus cell apoptosis induced by GLP-2 (11) may lead to increased accumulation of BB hydrolases and, therefore, partially account for the increased BB activity. Nonetheless, the selective and region-specific effects of GLP-2 suggest other mechanisms may be involved. In agreement with others, we report that parenteral and enteral feeding have different effects on BB hydrolases function. Parenterally fed, prematurely delivered 6-d-old piglets had increased LPH and maltase activities relative to piglets fed enterally, leading us to suggest that TPN may induce precocious development of disaccharidase activities in neonatal pigs, similarly as in rabbits (4).

Both GLP-2 and enteral nutrition appear to primarily control disaccharidase activity at the level of transcription, as indicated by the parallel changes in mRNA levels and activities and possibly by increasing the stability of the mRNA. A role for GLP-2 in regulating BB gene expression has previously been

(A)

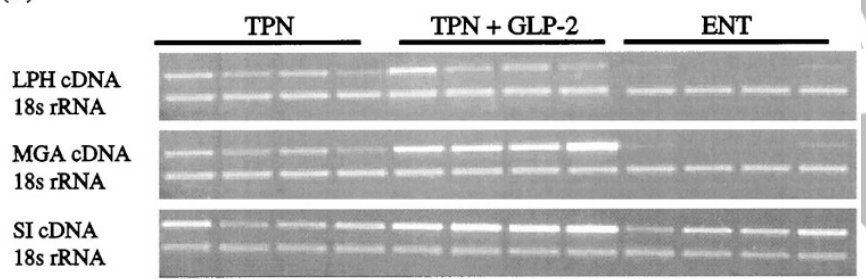

(B)

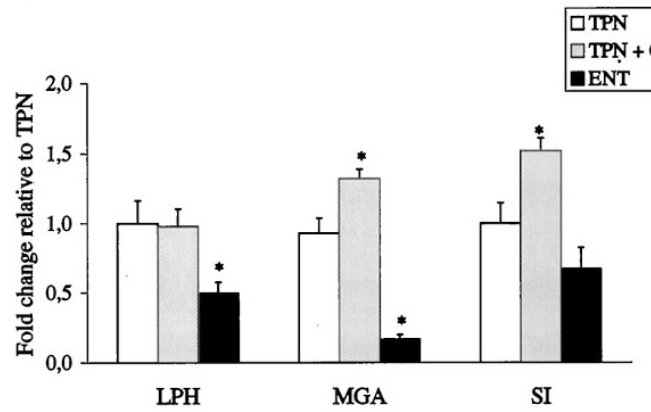

(C)

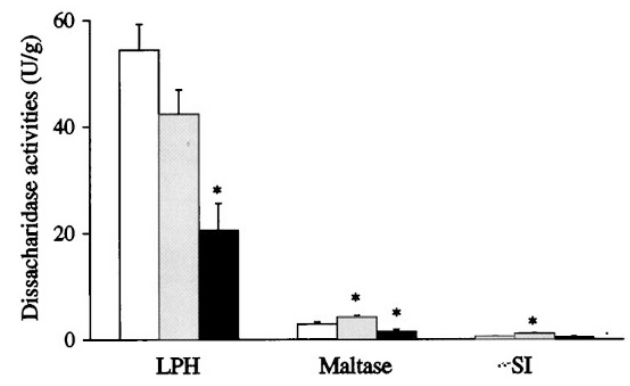

Figure 1. Jejunal disaccharidase gene expression and activity (U/g tissue) in 6-d-old piglets administered parenteral nutrition, parenteral nutrition and GLP-2, or enteral nutrition. (A) Representative reverse transcription PCR gel showing LPH, MGA, and SI mRNA and 18s rRNA abundance in TPN, GLP-2, and ENT piglets. (B) LPH, MGA, and SI mRNA/18s rRNA in GLP-2 $(n=8)$ and ENT $(n=6)$ piglets relative to TPN controls $(n=7)$. (C) LPH, MGA, and SI activities. Values are means \pm SEM. ${ }^{*} p<0.05$ relative to TPN. examined and the investigators concluded that the regulatory element, Cdx-2, did not appear to be involved in GLP-2mediated enhanced SI gene expression (14). The lack of effect of GLP-2 on SI and LPH mRNA levels, in this study, supports the evidence that $\mathrm{Cdx}-2$ is most likely not involved in mediating the effects of GLP-2 on enzyme transcription (22). We suggest that GLP-2 may alter the expression and/or binding activity of putative common nuclear factor(s) to the promoter region to regulate gene transcription.

The effects of GLP-2 and enteral feeding on disaccharidase mRNA abundance are fundamentally different, as is obvious in the case of MGA. As mentioned earlier, GLP-2 is thought to

(A)

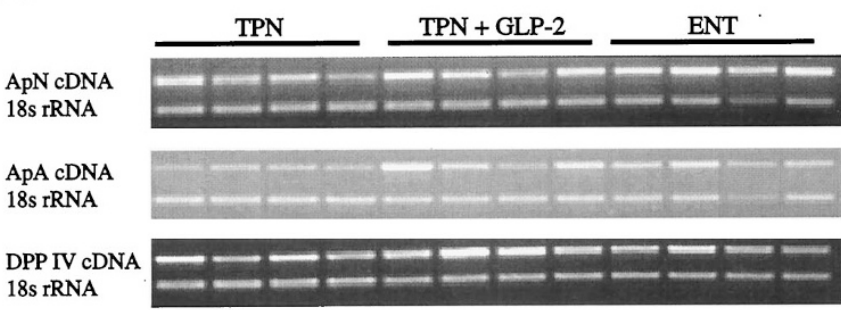

(B)

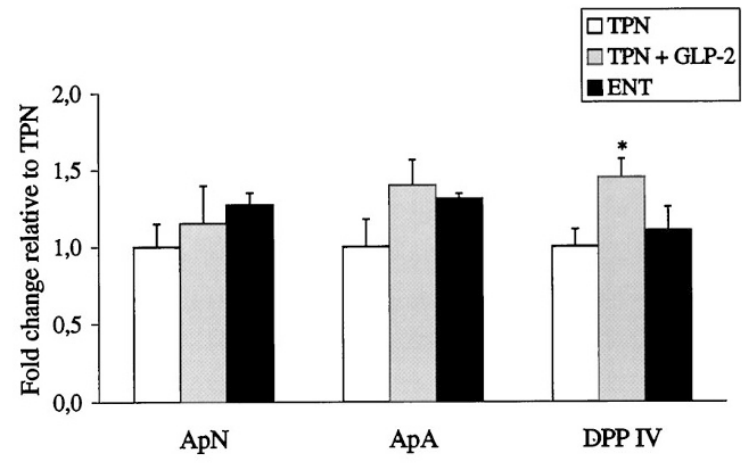

(C)

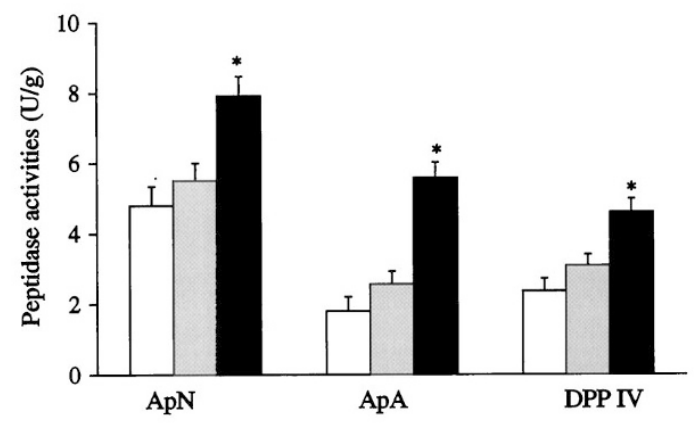

Figure 2. Ileal peptidase gene expression and activity (U/g tissue) in 6-d-old piglets administered parenteral nutrition, parenteral nutrition and GLP-2, or enteral nutrition. (A) Representative reverse transcription PCR gel showing ApN, ApA, and DPP IV mRNA and 18s rRNA abundance in TPN, GLP-2, and ENT piglets. ( $B) \mathrm{ApN}$, ApA, and DPP IV mRNA/18s rRNA in GLP-2 $(n=8)$ and ENT $(n=6)$ piglets relative to TPN controls $(n=7)$. (C) ApN, ApA, and DPP IV activities. Values are means \pm SEM. ${ }^{*} p<0.05$ relative to TPN. 
partly mediate the effects of enteral nutrition on gut growth and function. The opposing effect of GLP-2 and enteral nutrition in MGA mRNA abundance and activity suggests that GLP-2 does not play a primary role in mediating the effects of enteral nutrition on intestinal function.

The administration of GLP-2 to parenterally fed pigs and enteral nutrition selectively increased peptidase activities across the intestine of premature neonatal piglets. Whereas GLP-2 selectively stimulated jejunal ApN activity, enteral nutrition enhanced the activities of all the peptidases studied. We suggest that the selective effect of GLP-2 may be due to the higher abundance of the GLP-2 receptor mRNA in the jejunum and/or to different signaling mechanisms (23). Because changes in enzyme mRNA abundance were not accompanied by any changes in enzyme, it appears that the peptidase enzymes are differently regulated than the disaccharidase enzymes in the neonatal pig intestine.

A clear difference in the response of BB hydrolases to parenteral and enteral nutrition is reported in this study. Differences in maltase and LPH and peptidase activities between parenterally and enterally fed piglets and the longitudinal distribution of $\mathrm{BB}$ hydrolases in the small intestine suggest that normal BB enzyme activity is dependent on the presence of luminal contents within the GIT. We also noted that pancreas weight was decreased in parenterally fed piglets. This atrophic effect of TPN has previously been reported in rabbits (4), and, although the significance of this difference is unclear, it indicates, once again, that the route of nutrient administration is crucial for normal small intestine function.

Another aim of this study was to compare the effect of GLP-2 on the premature newborn gut with the previously reported effect on the term newborn gut where GLP-2 stimulated intestinal growth $(+20 \%)$ and significantly increased MGA mRNA abundance and activities in the jejunum (15). In addition to stimulating intestinal growth and MGA, GLP-2 also stimulated SI and ApN enzyme function in premature piglets, showing that the premature neonatal intestine was more responsive to exogenous GLP-2 than the term neonatal intestine. The small differences between premature and term pigs may be explained by alterations in the localization and downstream signaling pathways of the GLP-2 receptor, as we have recently shown that GLP-2 receptor mRNA expression increases in the small intestine with gestational age (unpublished observations).

Although GLP-2 does not parallel the effects of enteral nutrition on enzyme activities in premature newborn pigs, the positive effects of GLP-2 in maintaining enzyme activity, coupled with increased small intestine mass (11) and the demonstrated ability of GLP-2 to decrease intestinal permeability (24) and improve nutrient absorption (25), suggests that GLP-2 could be of great clinical significance in the treatment of the immature intestine.

We conclude that GLP-2 and enteral nutrition exert different effects on small intestinal BB enzyme function despite similar effects on growth. This would indicate that GLP-2 supplementation of TPN will not normalize small intestinal BB enzyme function to the level present in enterally fed neonates. In addition, we have shown that some of the effects of GLP-2 on small intestinal BB function are dependent on gestational age at birth.
Acknowledgments. The authors thank Bolette Hartmann, Jens J. Holst, Kelly Tappenden, Douglas G. Burrin, and Randy Buddington for their contributions to the design and analysis of this study. We also thank Ebba de Neergaard Harrison and Anna Siekierska for skilled technical assistance.

\section{REFERENCES}

1. Chance WT, Foley-Nelson T, Thomas I, Balasubramaniam A 1997 Prevention of parenteral nutrition-induced gut hypoplasia by coinfusion of glucagon-like peptide-2. Am J Physiol 273:G559-G563

2. Guedon C, Schmitz J, Lerebours E, Metayer J, Audran E, Hemet J, Colin R 1986 Decreased brush border hydrolase activities without gross morphologic changes in human intestinal mucosa after prolonged total parenteral nutrition of adults. Gastroenterology 90:373-378

3. Raul F, Galluser M, Doffoel M 1984 Stimulation of disaccharidase activities in the jejunal brush border membrane of adult rat by total parenteral nutrition. Effects of thyroid hormones. Digestion 29:190-196

4. Gall DG, Chung M, O'Loughlin EV, Zahavi I, Opleta K 1987 Effects of parenteral and enteral nutrition on postnatal development of the small intestine and pancreas in the rabbit. Biol Neonate 51:286-296

5. Burrin DG, Stoll B, Jiang R, Chang X, Hartmann B, Holst JJ, Greeley Jr GH, Reeds PJ 2000 Minimal enteral nutrient requirements for intestinal growth in neonatal piglets: how much is enough? Am J Clin Nutr 71:1603-1610

6. Drucker DJ, Erlich P, Asa SL, Brubaker PL 1996 Induction of intestinal epithelial proliferation by glucagon-like peptide 2. Proc Natl Acad Sci U S A 93:7911-7916

7. Cheeseman CI 1997 Upregulation of SGLT-1 transport activity in rat jejunum induced by GLP- 2 infusion in vivo. Am J Physiol 273:R1965-R1971

Brubaker PL, Izzo A, Hill M, Drucker DJ 1997 Intestinal function in mice with small bowel growth induced by glucagon-like peptide-2. Am J Physiol 272:E1050-E1058

9. Munroe DG, Gupta AK, Kooshesh F, Vyas TB, Rizkalla G, Wang H, Demchyshyn L, Yang ZJ, Kamboj RK, Chen H, McCallum K, Sumner-Smith M, Drucker DJ, Crivici A 1999 Prototypic G protein-coupled receptor for the intestinotrophic factor glucagon-like peptide 2. Proc Natl Acad Sci U S A 96:1569-1573

10. Xiao Q, Boushey RP, Drucker DJ, Brubaker PL 1999 Secretion of the intestinotropic hormone glucagon-like peptide 2 is differentially regulated by nutrients in humans Gastroenterology 117:99-105

11. Burrin DG, Stoll B, Jiang R, Petersen YM, Elnif J, Buddington RK, Schmidt M, Holst JJ, Hartmann B, Sangild PT 2000 GLP-2 stimulates intestinal mucosal growth by suppressing proteolysis and apoptosis in parenterally fed premature piglets Am J Physiol 279:G1249-G1256

12. Castro GA, Copeland EM, Dudrick SJ, Johnsonn LR 1975 Intestinal disaccharidase and peroxidase activities in parenterally nourished rats. J Nutr 105:776-781

13. Park YK, Monaco MM, Donovan SM 1998 Delivery of total parenteral nutrition (TPN) via umbilical catheterization: development of a piglet model to investigate therapies to improve gastrointestinal structure and enzyme activity during TPN. Biol Neonate 73:295-305

14. Kitchen PA, Fitzgerald AJ, Goodlad RA, Barley NF, Ghatei MA, Legon S, Bloom SR, Price A, Walters JR, Forbes A 2000 Glucagon-like peptide-2 increases sucraseisomaltase but not caudal- related homeobox protein-2 gene expression. Am J Physiol 278:G425-G428

15. Petersen YM, Burrin DG, Sangild PT 2001 GLP-2 has differential effects on small intestine growth and function in fetal and neonatal pigs. Am J Physiol Regul Integr Comp Physiol 281:R1986-R1993

16. Silver M, Comline RS, Fowden AL 1983 Fetal and maternal endocrine changes during the induction of parturition with the PGF analogue, cloprostenol, in chronically catheterized sows and fetuses. J Dev Physiol 5:307-321

17. Wykes LJ, Ball RO, Pencharz PB 1993 Development and validation of a total parenteral nutrition model in the neonatal piglet. J Nutr 123:1248-1259

18. Hartmann B, Harr MB, Jeppesen PB, Wojdemann M, Deacon CF, Mortensen PB, Holst JJ 2000 In vivo and in vitro degradation of glucagon-like peptide-2 in humans. J Clin Endocrinol Metab 85:2884-2888

19. Chomczynski P, Sacchi N 1987 Single-step method of RNA isolation by acid guanidinium thiocyanate-phenol-chloroform extraction. Anal Biochem 162:156-159

20. Sangild PT, Sjostrom H, Noren O, Fowden AL, Silver M 1995 The prenatal development and glucocorticoid control of brush-border hydrolases in the pig small intestine. Pediatr Res 37:207-212

21. Park YK, Monaco MH, Donovan SM 1999 Enteral insulin-like growth factor-I augments intestinal disaccharidase activity in piglets receiving total parenteral nutrition. J Pediatr Gastroenterol Nutr 29:198-206

22. Fang R, Santiago NA, Olds LC, Sibley E 2000 The homeodomain protein Cdx2 regulates lactase gene promoter activity during enterocyte differentiation. Gastroenterology 118:115-127

23. Yusta B, Huang L, Munroe D, Wolff G, Fantaske R, Sharma S, Demchyshyn L, Asa SL, Drucker DJ 2000 Enteroendocrine localization of GLP-2 receptor expression in humans and rodents. Gastroenterology 119:744-747

24. Kouris GJ, Liu Q, Rossi H, Djuricin G, Gattuso P, Nathan C, Weinstein RA, Prinz RA 2001 The effect of glucagon-like peptide 2 on intestinal permeability and bacterial translocation in acute necrotizing pancreatitis. Am J Surg 181:571-575

25. Jeppesen PB, Hartmann B, Thulesen J, Graff J, Lohmann J, Hansen BS, Tofteng F, Poulsen SS, Madsen JL, Holst JJ, Mortensen PB 2001 Glucagon-like peptide 2 improves nutrient absorption and nutritional status in short-bowel patients with no colon. Gastroenterology 120:806-815 